Galia Wardha Alvita, Sholihul Huda, Hubungan Tipe Kepribadian Dengan Tingkat Interaksi Sosial Lansia Di Panti Wredha Sultan Fatah Demak

\title{
HUBUNGAN TIPE KEPRIBADIAN DENGAN TINGKAT INTERAKSI SOSIAL LANSIA DI PANTI WREDHA SULTAN FATAH DEMAK
}

\author{
Galia Wardha Alvita \\ STIKES Cendekia Utama Kudus, gwardha@gmail.com \\ Sholihul Huda \\ STIKES Cendekia Utama Kudus, huda shol@gmail.com
}

\begin{abstract}
ABSTRAK
Latar Belakang : usia yang semakin tua pada lansia akan diikuti dengan perubahan interaksi sosial. Perubahan interaksi sosial lansia menimbulkan keterbatasan dalam berhubungan dengan orang lain dan mempengaruhi kepuasan dalam hidup. Perubahan interaksi sosial tersebut dipengaruhi pula oleh pengalaman tipe kepribadian dimasa mudanya yaitu tipe kepribadian tertutup ataupun terbuka. Penelitian ini bertujuan untuk mengetahui Hubungan Tipe Kepribadian Dengan Tingkat Interaksi sosial pada Lansia di Panti Wredha Sultan Fatah Demak.

Metode : Jenis penelitian adalah deskriptif korelasi dengan rancangan cross sectional. Jumlah sampel dalam penelitian ini 30 responden dengan teknik pengambilan sampel total sampling. Analisa penelitian menggunakan Chi Kuadrat.

Hasil : sebagian besar lansia mempunyai tipe kepribadian introvert yaitu 16 responden $(53,3 \%)$, dan sebagian kecil lansia mempunyai tipe kepribadian ekstrovet yaitu 14 responden (46.7\%). Sebagian besar lansia memiliki tingkat interaksi sosial kurang sebanyak 18 responden (60\%) dan tingkat interaksi sosial baik sebanyak 12 responden (40\%) dengan nilai $p$-value 0,024 ( $<<0.05)$.

Kesimpulan : Ada Hubungan Tipe Kepribadian Dengan Tingkat Interaksi sosial pada Lansia di Panti Wredha Sultan Fatah Demak. Berdasarkan hasil analisis statistik tersebut memberikan informasi umum yang berkaitan dengan hubungan tipe kepribadian dengan bagaimana lansia dalam berinteraksi sehingga dapat merumuskan intervensi yang tepat dalam meningkatkan interaksi sosial lansia sesuai dengan tipe kepribadiannya
\end{abstract}

Kata Kunci $\quad$ : Interaksi Sosial, Kepribadian, Lansia

\begin{abstract}
Background: The aging process in the elderly will be followed by psychososial changes. Psychososial changes that occur result in disruption of sosial interaction of the elderly and lead to dependence on others and satisfaction in life. Psychoanalytic changes are also influenced by the experience of personality types in his youth. This study aims to determine the relationship between the type of personality and the level of sosial interaction in the elderly at the Panti Wredha Sultan Fatah Demak.

Method: The type of research is descriptive correlation with cross sectional design. The number of samples in this study were 30 respondents with a total sampling technique. Research analysis uses Chi Squares.

Results: most of the elderly have introverted personality types, namely 16 respondents (53.3\%), and a small portion of the elderly have extrovet personality types, namely 14 respondents (46.7\%).
\end{abstract}


Galia Wardha Alvita, Sholihul Huda, Hubungan Tipe Kepribadian Dengan Tingkat Interaksi Sosial Lansia Di Panti Wredha Sultan Fatah Demak

Most of the elderly have a level of sosial interaction less than 18 respondents (60\%) and a good level of sosial interaction as many as 12 respondents $(40 \%)$ with a $p$-value of $0.024(p<0.05)$.

Conclusion: There is a Relationship between Personality Types and the Level of Sosial Interaction in the Elderly at the Panti Wredha Sultan Fatah Demak. Based on the results of the statistical analysis, it provides general information relating to the relationship of personality types with how the elderly interact so that they can form appropriate interventions in increasing sosial interaction of the elderly according to their personality type.

Keywords : Diet pattern, History of hypertension, Elderly

\section{PENDAHULUAN}

Menua merupakan proses alami yang akan dihadapi manusia, dan ini juga merupakan tahap yang paling penting di dalam kehidupan. Pada tahap ini secara alami lanjut usia mengalami penurunan kondisi fisik, psikologis maupun interaksi sosial yang saling berinteraksi satu sama lain. Dimasa ini manusia mengalami kemunduran fisik, mental maupun sosial secara bertahap dan muncul berbagai penyakit degeneratif (Azizah, 2011). Kemunduran fisik maupun mental tersebut mengakibatkan menurunnya derajat kesehatan, kehilangan pekerjaan dan penurunan kemampuan fisik yang akan mengakibatkan orang lanjut usia secara perlahan menarik diri dari hubungan dengan sekelilingnya hal ini dapat mempengaruhi interaksi psikososial lansia (Vicky, 2012). Berkurangnya interaksi sosial pada lansia dapat menyebabkan perasaan terisolir, sehingga lansia menyendiri dan mengalami isolasi sosial yang pada akhirnya lansia bisa depresi dan dapat mempengaruhi kualitas hidup lansia (Andreas, 2012). Lansia yang berada dalam keadaan normal seharusnya masih dapat berinteraksi dengan teman sebaya, mampu menerima atau merasa puas bahwa kehidupannya masih berharga dan harus dijadikan cerminan, akan tetapi bila tidak dapat menerima kehidupan maka akan memasuki keadaan keputusan dan ketidakberdayaan yang dapat menyebabkan gangguan depresi (Sari, 2016).
Menurut Peraturan Pemerintah Republik Indonesia Nomor 43 Tahun 2004, lanjut usia adalah seseorang yang telah mencapai usia 60 (enam puluh) tahun ke atas. Secara global populasi lansia diprediksi terus mengalami peningkatan. Dari Asia dan Indonesia dari tahun 2015 sudah memasuki era penduduk menua (ageing population) karena jumlah penduduknya yang berusia 60 tahun ke atas (penduduk lansia) melebihi angka $7 \%$. Berdasarkan data proyeksi penduduk, diperkirakan tahun 2017 terdapat 23,66 juta jiwa penduduk lansia di Indonesia (9,03\%). Diprediksi jumlah penduduk lansia tahun 2020 (27,08 juta), tahun 2025 (33,69 juta), tahun 2030 (40,95 juta) dan tahun 2035 $(48,19$ juta). Ada 19 provinsi (55,88\%) provinsi Indonesia yang memiliki struktur penduduk tua, apat dilihaat tiga provinsi dengan persentase lansia terbesar adalah DI Yogyakarta (13,81\%), Jawa Tengah (12,59\%) dan Jawa Timur (12,25\%). Angka harapan hidup perempuan $(9,53 \%)$ lebih tinggi daripada laki-laki (8,54\%), hal ini terlihat dengan keberadaan penduduk lansia perempuan yang lebih banyak dari pada lansia laki-laki (kementrian kesehatan RI, 2017). Sedangkan menurut Dinas Sosial P2PA Kabupaten Demak jumlah penduduk lansia dari kota demak sendiri tahun 2017 jumlah lansia sekitar 54.126 lansia.

Ciri kepribadian dikenal dengan dua istilah yaitu kepribadian introvert dan kepribadian ekstrovert. Keduatipe tersebut menggambarkan bagiamana sesorang 
berinteraksi. Tipe introvert lebih mengutamakan pemikiran, perasaan, keinginan sendiri menjadi sumber dan minatnya. Senang dengan aktivitas merenung dan merencanakan sehingga sering tampak menyendiri, tingkah laku lamban dan ragu-ragu (Sabri,2001). Kepribadian introvert Tidak suka melibatkan orang banyak dalam kehidupannya. Berbeda halnya dengan Tipe kepribadian ekstrovert yang lebih berorientasi pada dunia luar. Pada psrinsipnya orang-orang dengan kepribadian ekstrovet bertindak cepat dalam mengambil keputusan karena orientasi hidupnya lebih mengarah kemasa kini. Tipe ini lebih suka pula aktif di tengah orang-orang sehingga mudah beradaptasi dan disukai oleh sekelilingnya (Iskandar, 2004). Sesuai dengan pendapat Costa dan McCrae bahwa kepuasan hidup dalam berinteraksi akan lebih mudah diperoleh bagi lansia yang berkepribadian ekstrovert daripada introvert (Afdol,1995).

Kepribadian merupakan salah satu factor yang mempengaruhi lansia dalam melakukan interaksi sosial. Interaksi sosial yang baik merupakan keberhasilan lansia dlam aktualisasi diri sehingga meningkatkan harapan lansia untuk hidup di panti wredha. Dari latar belakang tersebut maka penelitian ini akan dicari penjelasan tentang "Hubungan Tipe Kepribadian dengan tingkat kepuasan Interaksi Lansia Penghuni Panti Wredha" dengan menggunakan pendekatan teori "Tiga A Kebahagiaan" yaitu sikap menerima (acceptance), kasih sayang (affection) dan prestasi (achievement).

Hasil survai dari Panti Wredha Sultan Fatah Demak, panti ini menampung sekitar 30 lansia. Para lansia yang tinggal di panti ini menurut pengurus panti, pada umumnya kabanyakan lansia yang di panti berasal dari individu yang terlantar, tidak mempunyai keluarga, tempat tinggal dan ada juga lansia yang masih mempunyai keluarga yang sengaja dititipkan di panti. Sehingga lansia di panti wredha sultan fatah memiliki kasus bervariasi dan cukup banyak. Pelayanan kesehatan yang di lakukan juga belum optimal hanya pemeriksaan kesehatan fisik yang rutin dijalankan pada hari selasa. Dan menurut pengurus panti ada beberapa lansia yang mengalami isolasi sosial. Hal ini dapat dilihat dari perilaku sedih, sering menyendiri dan susah tidur.

\section{METODE PENELITIAN}

Penelitian ini berjenis penelitian kuantitatif, dengan desainnya adalah deskriptif korelasional, dan menggunakan pendekatan cross sectional, populasi dalam penelitian ini adalah Lansia di Panti Wredha Sultan Fatah Demak., sampel dalam penelitian ini sebanyak 30 responden. Teknik sampling dalam penelitian ini menggunakan total sampel. Karakteristik responden yaitu kriteria inklusi yaitu lansia yang tinggal di Panti Wredha Sultan Fatah Demak, lansia yang mampu berkomunikasi dengan baik, lansia yang berumur lebih dari 60 tahun. Sedangkan kriteria ekslusi yaitu, lansia yang menolak untuk menjadi responden,. Penelitian dilakukan pada bulan September Desember 2018 di Panti Wredha Sultan Fatah Demak, instrument penelitian ini menggunakan kuesioner. Analisa dalam penelitian ini menggunakan Chi Square.

\section{HASIL PENELITIAN DAN PEMBAHASAN}

1. Tipe Kepribadian lansia

Tabel 1

Distribusi Frekuensi Tipe kepribadian lansia di panti Wredha Sultan Fatah Demak Desember 2018 ( $n=30)$

\begin{tabular}{ccc}
\hline $\begin{array}{c}\text { Tipe } \\
\text { Kepribadian }\end{array}$ & Frekuensi & $\begin{array}{c}\text { Presentase } \\
(\%)\end{array}$ \\
\hline Ekstrovet & 14 & 46,7 \\
Introvet & 16 & 53,3 \\
\hline Total & $\mathbf{3 0}$ & $\mathbf{1 0 0}$ \\
\hline
\end{tabular}


Berdasarkan tabel 1 menunjukkan distribusi responden berdasarkan tipe kepribadian dari 30 responden, didapatkan 16 lansia (53,3\%) mempunyai tipe kepribadian Introvet, dan 14 lansia (46,7\%) memiliki kepribadian ekstrovet. Hasil penelitian ini sejalan dengan penelitian Jamil (2015) yang menunjukkan bahwa mayoritas lansia memiliki tipe kepribadian Introvert yaitu sebesar 55 $\%$. Tipe introvert lebih mengutamakan hasil pemikiran sendiri dengan menggunakan perasaannya, memiliki keinginan sendiri yang sulit diungkapkan ke orang lain menjadi sumber dan minatnya, menyenangi, merenung dan merencanakan sehingga sering tampak menyendiri, tingkah laku lamban dan ragu-ragu (Sabri, 2001).

Sedangkan tipe ekstrovert berorientasi kedunia luar. Berprinsip praktis, cepat bertindak dan cepat mengambil keputusan karena orientasi hidup masa (2004),Kepribadian berubah dan berkembang terus seiring dengan bagaimana seseorang terpapar dan beradaptasi dengan lingkungannya.

Setiap terjadi perubahan pada lingkungan akan kini. Tipe ini aktif di tengah orang-orang sehingga mudah menyesuaikan diri dan biasanya disenangi lingkungannya (Iskandar, 2004). Menurut Sunaryo diikuti pula dengan perubahan kepribadiannya. Hurlock (Miller, 2004) juga menyatakan bahwa adanya perubahan yang terjadi pada lansia akibat proses menua akan mempengaruhi konsep diri lansia sehingga kepribadianya juga berubah. Penurunan kondisi fisik yang semakin melemah seiring dengan pertambahan usia dan Perubahan status sosial mengakibatkan lansia cenderung memiliki tipe kepribadian introvert. Menurut Nugroho ( 2004) bahwa perubahan kepribadian terjadi tidak dengan drastis tetapi bertahap dengan bertambahnya usia dan bagaimana orang tersebut terpapar dengan lingkungan.

Menurut Selo Sumardjan dan Soelaiman Soemardi (1991), manusia merupakan makhluk sosial yang tidak dapat hidup sendiri mereka membutuhkan orang lain untuk bertahan hidup, selain itu setiap manusia juga memiliki sifat yang berbeda-beda dalam memaknai dirinya sesuai dengan konsep dan ideal dirinya, sehingga mereka memiliki keinginan dan mendahulukan kepentingannya sendiri. Sesuai dengan bertambahnya usia konsep dan ideal diri ini akan mempengaruhi perubahan tipe kepribadian dikarenakan pola piker dalam menghadapi hidup yang berubah.

Lansia cenderung mengalami kepribadian introvert dikarenakan lansia mulai beradaptasi terhadap perubahan fisik dan psikis yang terjadi akibat proses menua. Mereka mulai berfikir tentang diri sendiri bahwa kondisi mereka sudah mulai melemah dengan bertambahnya usia. Dampaknya mereka menjadi suka merenung diri, membatasi diri dan bersikap seperti orang berusia lanjut. mereka senang untuk merngingat dan berfikir tentang masa-masa lalu/ pengalaman yang pernah dialami, keadaan saat ini dan masa yang akan datang. Lansia juga lebih banyak berakifias untuk mempersiapkan diri menjelang kematian daripada berinteraksi dengan orang lain yaitu dengan lebih banyak beribadah, berdoa dan berdzikir untuk mendekatkan diri pada Yang Maha Kuasa (Ulfiana, 2005). 
Hal ini pula yang dialami oleh responden berdasarkan hasil kuesioner yang menunjukkan bahwa sebagian besar lansia senang mengikuti kegiatan pengajian rutin di panti, lebih suka tiduran di kamar karena lelah atau malas, merasa malu apabila harus menyapa teman terlebih dahulu serta sering merasakan kebosanan di dalam panti.

Mereka mempunyai perasaan sensitif sehingga mereka tidak mudah bergaul dengan orang lain didalam panti. Kebanyakan lansia juga memiliki rasa kurang percaya diri sehingga jarang mereka mau tampil dalam mengemukakan pendapat, tidak suka keramaian. Lansia yang memiliki kepribadian introvert lebih suka sendiri, kurang berminat dengan orang baru, kurang percaya diri untuk tampil di depan umum, jarang untuk mendahului dalam berkomunikasi , khususnya menyapa orang baru, terlihat asing bila bersama orang lain, mudah tersinggung oleh perkataan orang lain (Iskandar, 2004).

Sebagian kecil lansia memiliki tipe kepribadian ekstrovert dimana mereka lebih aktif dalam berkomunikasi, suka bergaul, dan lebih mudah beradaptasi dengan lingkungan baru.. Dari hasil penelitian ini lansia yang memiliki tipe kepribadian Ekstrovert sebesar 46,7\%. Lansia yang memiliki kepribadian ekstrovert yang tinggal di panti wredha memiliki kemampuan untuk berinteraksi dengan orang lain dengan beragam latar belakang dan keinginan.. Jika mereka saling bertemu maka mereka akan mudah untuk bercerita tentang kehidupan masa lalu maupun masa kini.

Hal ini terlihat pada respon lansia yang kebanyakan dari mereka menyatakan senang berkumpul, menonton televise bersama, mendiskusikan Koran yang telah dibaca dan lain-lain, karena dengan berkumpul dapat menghilangkan rasa kesepian dan kesedihan. Lansia yang memiliki kepribadian ekstrovert dapat mudah mendapatkan teman dan pertolongan orang lain saat mengalami kesulitan. Selain itu mereka juga cenderung lebih berani dan percaya diri saat tampil di depan umum.

2. Tingkat Interaksi Sosial lansia

Tabel 2

Distribusi Frekuensi Tingkat Interaksi Sosial Lansia di panti Wredha Sultan Fatah Demak, Desember $2018(n=30)$

\begin{tabular}{ccc}
\hline $\begin{array}{c}\text { Tingkat } \\
\text { Interaksi } \\
\text { Sosial }\end{array}$ & Frekuensi & $\begin{array}{c}\text { Presentase } \\
(\%)\end{array}$ \\
\hline Baik & 12 & 40 \\
Kurang & 18 & 60 \\
\hline Total & $\mathbf{3 0}$ & $\mathbf{1 0 0}$ \\
\hline
\end{tabular}

Berdasarkan tabel 2 menunjukkan distribusi responden berdasarkan tingkat interaksi dari 30 responden, didapatkan 18 lansia (60\%) mempunyai tingkat interaski kurang, dan 12 lansia (40\%) memiliki tingkat interaksi baik. Mayoritas lansia memiliki interaksi yang kurang dikarenakan kemampuan berkomunikasi akibat kelemahan dan perubahan fisik, jarang berbaur dan berkumpul dengan teman-temannya serta lebih suka menyendiri. Hasil penelitian ini sejalan dengan pendapat Soekanto (2005) yang menunjukkan bahwa seseorang yang memasuki masa lansia, mereka mulai membatasi diri dari masyarakat, dan aktivitasnya banyak berfokus pada dirinya sendiri.

Interaksi sosial merupakan suatu hubungan yang terjadi antarmanusia yang memiliki timbal balik satu dengan yang lain, saling memberikan pengaruh 
dalam pikiran dan tindakan dalam kehidupan sehari-hari. Setiap individu memiliki kebutuhan untuk berinteraksi dengan orang lain sampai akhir hayat Kebutuhan untuk berinteraksi dengan orang lain akan dimiliki oleh individu sampai akhir hayat tetapi kebutuhan tersebut tidak smua lansia memenuhinya sebagian dari mereka merasa kesepian tidak memiliki teman untuk berinteraksi dan berbagi masalah Menurut Hamka (2009, dalam Fitria 2011), sebagian besar lansia mengalami masalah dalam interaksi sosial. Semakin bertambah umur lansia semakin berkurang kemampuan lansia dalam berinteraksi sosial sehingga merasakan kesulitan saat bergaul dengan orang lain, dikarenakan proses menua yang dialami lansia menimbulkan proses degenerative dari segi fisik maupun mental yang mengakibatkan menurunnya kemampuan fisik dan derajat kesehatan sehingga mereka perlahan menarik diri dari masyarakat dan lingkungan sekitar.

Kecenderungan penurunan kemampuan interaksi sosial pada lansia dikarenakan kerusakan kognitif, kematian orang terdekat, dan fasilitas perawatan sehari-hari. Seseorang akan memiliki Kebutuhan untuk berinteraksi dengan orang lain sampai seumur hidup demikian pula dengan lansia. Namun pada lansia sebagian besar hal ini menjadi kendala disaat para lansia kehilangan pasangannya yang membawa perubahan pada bagaimana lansia berinteraksi. Lansia merasa kehilangan orang yang dicitainya dan tidak lagi ada yang memberikan dukungan dalam hidup hal ini dapat mempengaruhi perasaan percaya diri dan dapat menurunkan kemampuan dalam berinteraksi dengan sosial.
Perasaan tidak percaya diri atau rendah diri merupakan salah satu perubahan psikis yang terjadi pada lansia yang dapat mempengaruhi lansia dalam beriteraksi sosial. Perasaan rendah diri tersebut seperti merasa tidak berguna, bersalah, dan merasa apa yang dilakukan tidak memiliki arti, hal ini mengakibatkan lansia cenderung menghabiskan waktu dengan tidur dan tidak memiliki minat kontak sosial. (Pieter \& Lubis, 2010) . Pada lansia ini didapatkan interaksi individu-individu lebih dominan daripada dengan kelompok. Meskipun interaksi antar individu baik namun untuk hal-hal tertentu saja yang sifatnya umum dan bukan hal-hal yang pribadi (Sanjaya, 2012). Hal ini terlihat pada hasil kuesioner yang menunjukkan sebagian lansia merasa malu jika berkumpul dengan orang banyak atau orang asing, pada saat berinteraksi tidak ada harapan atau tujuan yang ingin dicapai baik yang disadari atau tidak. Hal ini dipengaruhi oleh beberapa hal, diantaranya alasan masuk panti yang sebagian besar masuk bukan karena keinginannya sendiri. Harapan-harapan pada saat masuk tersebut ada sebagian yang sudah tercapai dan masih ada yang belum tercapai sehingga menyebabkan lansia tidak lebih mudah untuk mencapai interaksi yang baik.

3. Hubungan Tipe Kepribadian Dengan Tingkat Interaksi Sosial

\section{Table 3}

Hasil Uji Korelasi Chi Square Tipe Kepribadian Dengan Tingkat Interaksi Sosial Lansia Di Panti Wredha Sultan Fatah Demak Desember 2018 (N: 30) 
Galia Wardha Alvita, Sholihul Huda, Hubungan Tipe Kepribadian Dengan Tingkat Interaksi Sosial Lansia Di Panti Wredha Sultan Fatah Demak

\begin{tabular}{|c|c|c|c|c|c|c|c|c|}
\hline \multirow[t]{3}{*}{$\begin{array}{c}\text { Tipe } \\
\text { Kepribadian }\end{array}$} & \multicolumn{4}{|c|}{$\begin{array}{c}\text { Tingkat Interaksi } \\
\text { Sosial }\end{array}$} & \multirow{2}{*}{\multicolumn{2}{|c|}{ Total }} & \multirow[t]{2}{*}{$\begin{array}{c}p \\
\text { value }\end{array}$} & \multirow[t]{2}{*}{ OR } \\
\hline & \multicolumn{2}{|c|}{ Baik } & \multicolumn{2}{|c|}{ Kurang } & & & & \\
\hline & $\mathrm{F}$ & $\%$ & $\mathrm{~F}$ & $\%$ & $\mathrm{f}$ & $\%$ & 0,024 & 7.800 \\
\hline Ekstrovet & 9 & 30 & 5 & 16,7 & 14 & 46,7 & & \\
\hline Introvet & 3 & 10 & 13 & 46,7 & 16 & 53,3 & & \\
\hline Total & 12 & 40 & 18 & 43,3 & 30 & 100 & & \\
\hline
\end{tabular}

Tabel 3 menunjukkan hasil analisis statistik Chi Square diperoleh $p$ value sebesar $0.024(<0,05)$ hal ini dapat disimpulkan bahwa Ho ditolak dan Ha diterima yang artinya ada hubungan yang signifikan antara Tipe Kepribadian dengan tingkat interaksi sosial lansia di Panti Wredha Sultan Fatah Demak. Menurut pendapat Costa dan McCrae yang dikutip Afdol (1995) bahwa lansia yang memiliki kepribadian ekstrovert akan lebih mudah untuk memiliki interaksi sosial yang baik, karena mereka memiliki kemampuan dalam menemukan manfaat dari dukungan sosial.

Sedangkan lansia yang memiliki kepribadian introvert menurut Afdol (1995), menyatakan bahwa mereka kurang akrab dengan banyak orang. Lingkungan panti yang tidak terlalu luas disertai tata tertib yang harus ditaati sangat memungkinkan lansia hanya tinggal di dalam panti saja karena secara fisik mengalami penurunan. Berdasarkan table 3 dapat dilihat bahwa interaksi sosial baik mayoritas dimiliki oleh responden dengan tipe kepribadian Ekstrovert.

Lansia yang memiliki tipe kepribadian Introvert dalam berinteraksi dengan orang lain atau kelompok lebih mempertahankan ego atau tradisi lama karena lansia sulit untuk beradaptasi pada sesuatu yang baru atau pada orang yang baru dikenal mereka akan terlihat kaku dan membatasi diri. Pada saat lansia yang memiliki kepribadian introvert berinteraksi satu dengan yang lain mereka cenderung melakukannya jika ada manfaat yang akan diterimanya.

Sedangkan dalam persaingan lansia yang memiiki kepribadian introvert kurang berespon, mereka tidak memiliki antusiasme untuk terlihat menonjol, merasa ragu-ragu dalam mengambil keputusan dan kurang percaya diri. Sedangkan pada kepribadian ekstrovert dalam berinteraksi dan bersaing mereka lebih percaya diri dan suka tampil di muka umum, dalam hidupnya berorientasi pada masa depan. Jika memiliki konflik dengan orang lain, kepribadian ektrivert cenderung untuk segera menyelesaikan masalah sehingga tidak larut dalam konflik berkepanjangan. Dalam hal akomodasi / penyesuaian, keberhasilan tipe introvert dalam mencapai kepuasan interaksi membutuhkan rentang waktu yang lebih lama daripada ekstrovert, karena masing-masing lansia mempunyai tujuan dan harapan untuk dicapai. Mereka akan menyatakan puas apabila tujuan dan harapan tersebut benar-benar telah dicapai.

Berdasarkan keterangan ini maka ada kelebihan dan kekurangan yang dimiliki tipe introvert dalam berinteraksi. Hal inilah yang mempengaruhi respon lansia terhadap tingkat tingkat interaksi sosial selama tinggal di panti wredha.

\section{KESIMPULAN}

Berdasarkan hasil penelitian diatas dapat dirumuskan kesimpulan sebagai berikut :

1 Tipe kepribadian lansia penghuni Panti Wredha Sultan Fatah Demak sebagian besar termasuk tipe Introvert (53,3\%).

2. Tingkat interaksi Sosial lansia penghuni Panti Wredha Sultan Fatah Demak didapatkan lansia dengan tingkat 
interaksi sosial kurang (60\%). Hal ini dipengaruhi faktor harapan khusus pada saat masuk panti.

3. Ada hubungan bermakna antara tipe kepribadian (ekstrovert dan introvert) dengan tingkat interaksi sosial lansia penghuni Panti Wredha Sultan Fatah Demak dengan nilai signifikansi $\mathrm{p}=$ 0,024 . Hal ini dapat dikatakan bahwa tipe kepribadian lansia menentukan tingkat interaksi sosial lansia

\section{SARAN}

1. Perlu adanya penyegaran (pelatihan) petugas panti dalam memberikan pelayanan supaya tidak formalitas saja namun dibutuhkan pelayanan dengan pendekatan "kasih sayang" terutama bagi lansia tipe introvert.

2. Perlu adanya penambahan jenis kegiatan sesuai dengan tipe kepribadian, untuk lansia ekstrovert yaitu aktivitas kelompok sosialisasi dengan metode dinamika kelompok, bermain peran, atau dengan diskusi dan tanya jawab. Sedangkan pada lansia introvert diberikan jenis kegiatan bersifat personal seperti membuat kerajinan tangan yang dibimbing seorang petugas / pengasuh dan secara bertahap yaitu mulai dari jenis interaksi individu dan individu,dilanjutkan interaksi individu dan kelompok dan akhirnya antara kelompok dan kelompok. Kegiatan dilakukan dengan berdasarkan kasih sayang dalam rangka meningkatkan kualitas interaksi lansia di dalam panti wredha.

3. Perlu adanya penambahan jenis pelayanan yaitu pelayanan psikologis (konsultasi dan pemeriksaan psikologis) untuk mengetahui lebih lanjut masalah dan konsep solusinya sesuai dengan tipe kepribadiannya .

4. Bagi peneliti selanjutnya perlu dilakukan penelitian lebih lanjut secara kualitatif tentang pegalaman interaksi sosial lansia.

\section{DAFTAR PUSTAKA}

Andreas (2012). Interaksi Sosial san Kualitas Hidup Lansia di Kelurahan Lansot. Journal Keperawatan, Kp, Volume 5 No 1 Ferbuari 2017, Tomohon Selatan

Azizah, Lilik Ma'rifatul. (2011). Keperawatan Lanjut Usia, ed 1. Graha IImu: Yogyakarta

Dewi, S., Rhosma, (2014), Buku Ajar Keperawatan Gerontik, [e-book], diakses tanggal 20 Febuari 2018, dari https://books.google.co.id

Dinas Kesehatan Jateng. 2012. Profil Kesehatan Provinsi Jawa Tengah Tahun 2012.

Dinkes Jateng, Semarang. Available Source: http://dinkesjateng.go.id/download/pdf. Retrieved October 20, 2014

Hurlock E.B (1998). Psikologi Perkembangan Suatu Pendekatan Sepanjang Rentang Kehidupan edisi 5. Penerbit Erlangga. Jakarta

Iskandar Y (2004). Test Personaliti edisi 4. Yayasan Dharma Graha. Jakarta

Jamil (2012). Kepuasan Interaksi Sosial Lansia dengan Tipe Kepribadian. Unpablished Skripsi. Universitas Muhammadiyah Malang

Kartono Kartini (1996). Psikologi Umum. Mandar Maju. Bandung

Notoatmodjo, Soekidjo. 2010. Metodologi penelitian kesehatan. Edisi Revisi. Jakarta: Rineka Cipt 
Galia Wardha Alvita, Sholihul Huda, Hubungan Tipe Kepribadian Dengan Tingkat Interaksi Sosial Lansia Di Panti Wredha Sultan Fatah Demak

Nugroho W (2008). Keperawatan Gerontic. EGC. Jakarta.

Nursalam (2003). Konsep dan Penerapan Metodologi Penelitian IImu Keperawatan. Salemba Medika. Jakarta

Padila. (2013). Buku Ajar Keperawatan Gerontik Dilengkapi aplikasi kasus asuhan keperawatan gerontik, terapi modalitas, dan sesuai kompetensi standar. Nuha Medik: Yogyakarta

Sabri Alisuf (2001). Pengantar Psikologi Umum \& Perkembangan. Pedoman IImu Jaya. Jakarta

Sari, I. Prafita, (2016), 'Pengaruh senam vitalisasi otak dengan tingkat depresi pada lansia di panti werdha mojopahit kabupaten mojokerto', Proseding seminar nasional, p.329-334
Sunaryo (2004). Psikologi Untuk Keperawatan. EGC. Jakarta

Vicky T (2012). Hubungan interaksi Sosial dengan kualitas hidup lansia di RW XI Kelurahan Ganting Parak Gadang Wilayah Kerja Puskesmas Andalas Padang. Diakses http//Respository.unand.ac.id/18627/ tanggal 26 April 2018

Kusumowardani, A., \& Puspitosari, A. (2014). Hubungan Antara Tingkat Depresi Lansia Dengan Interaksi Sosial Lansia Di Desa Sobokerto Kecamatan Ngemplak Boyolali. Interest: Jurnal Ilmu Kesehatan, 3(2)

Sanjaya, A., \& Rusdi, I. (2012). Hubungan Interaksi Sosial Dengan Kesepian Pada Lansia. Jurnal Penelitian. Fakultas Keperawatan Universitas Sumatera Utara 